\title{
Radioiodination of Human Intrinsic Factor
}

\author{
Iain L. Mackenzie, Robert M. Donaldson, Jr., and \\ ROBERT F. SCHILLING \\ From the Department of Medicine, University of Wisconsin Medical School, \\ Madison, Wisconsin 53706, and Boston University School of Medicine, \\ Boston, Massachusetts 02118
}

A в S TRACT Human intrinsic factor (IF) saturated with ${ }^{80} \mathrm{Co}$-labeled cyanocobalamin $\left({ }^{80} \mathrm{CoB}_{12}\right)$ was purified and then iodinated with ${ }^{125} \mathrm{I}$ to yield ${ }^{125} \mathrm{I}$-labeled $\mathrm{IF}-{ }^{00} \mathrm{CoB}_{12}$ preparations of high specific activity. Sephadex G200 and DEAE-cellulose chromatography of the iodinated $\mathrm{IF}_{-}{ }^{\mathrm{e}} \mathrm{CoB}_{12}$ complex showed coincidence of the major ${ }^{125} \mathrm{I}$ and the ${ }^{80} \mathrm{Co}$ radioactivity peaks. During starch-gel electrophoresis ${ }^{60} \mathrm{Co}$ radioactivity from noniodinated and iodinated complexes migrated to the same extent while ${ }^{125}$ I radioactivity from the iodinated complex migrated slightly further anodally than did the ${ }^{\circ 0} \mathrm{Co}$ radioactivity. After the iodinated complex was mixed with antibody to the IF- $\mathrm{B}_{12}$ complex (antibody II) the ${ }^{125} \mathrm{I}$ and ${ }^{80} \mathrm{Co}$ radioactivity were: $(a)$ precipitated in similar amounts by antiglobulin serum, $(b)$ eluted coincidentally in the 19 S region on Sephadex G200, and (c) excluded to the same extent from starch gel during electrophoresis. After equilibrium exchange of IF "blocking" antibody (antibody I) for ${ }^{80} \mathrm{Co}$-vitamin $\mathrm{B}_{12}$ on ${ }^{125} \mathrm{I}$-labeled IF, ${ }^{125} \mathrm{I}$ radioactivity from the IF-antibody I complex: $(a)$ was precipitated by antiglobulin serum, $(b)$ was eluated in the 19S region on Sephadex G200 gel filtration, and (c) migrated slowly towards the anode on starch-gel electrophoresis. Urinary excretion of ${ }^{80} \mathrm{Co}$ radioactivity in pernicious anemia patients after oral administration of ${ }^{80} \mathrm{Co}$-vitamin $\mathrm{B}_{12}$ bound to freshly prepared ${ }^{125} \mathrm{I}$-labeled IF was similar to that obtained with noniodinated intrinsic factor.

These results show that iodination of $\mathrm{IF}^{-60} \mathrm{CoB}_{12}$ complex does not markedly alter the chromatographic, electrophoretic, antigenic, or absorption-promoting properties of IF.

\section{INTRODUCTION}

Ignorance of the precise role of intrinsic factor (IF) in the physiological absorption of vitamin $B_{12}$ persists

Preliminary reports of this work have appeared in abstract form $(1,2)$.

Received for publication 23 September 1968. despite nearly $40 \mathrm{yr}$ of investigation. Of particular importance in preventing progress in this field is the fact that presently available methods of tracing IF action depend on binding of $I F$ to vitamin $B_{12}$ labeled with a radioactive marker. Dependence on binding to radioactive vitamin $\mathrm{B}_{12}$ prevents examination of the metabolism of IF itself, and only an independently labeled IF can overcome this difficulty.

In an attempt to obtain. a suitably labeled IF preparation, human IF was first purified by the method of Chosy and Schilling ( 3 ) and then iodinated with ${ }^{125} \mathrm{I}$ by the technique of Greenwood, Hunter, and Glover (4). To determine whether iodination had altered the IF- $\mathrm{B}_{12}$ complex, the chromatographic, electrophoretic, antigenic, and absorption-promoting properties of purified preparations of IF were compared before and after iodination. The results indicate that ${ }^{125}$ I-labeled IF- $\mathrm{B}_{12}$ is sufficiently similar to unlabeled IF to serve as a tracer of IF.

\section{METHODS}

Purification of human intrinsic factor. Human IF possessing a high degree of purity was prepared from human gastric juice by a modification of the method of Chosy and Schilling (3). Gastric juice was obtained from patients with peptic ulcer during routine gastric secretory studies. Specimens were collected in iced containers after intramuscular injection of $1.5 \mathrm{mg}$ of Histalog/ $\mathrm{kg}$ body weight. The crude juice was filtered through glass wool, raised to $\mathrm{pH} 10$ with $\mathrm{NaOH}$ to inactivate pepsin (18), titrated to $\mathrm{pH}$ 7.0 with $\mathrm{HCl}$ and stored in 2-liter pools at $-20^{\circ} \mathrm{C}$. To $500 \mathrm{ml}$ of pooled gastric juice was added sufficient ${ }^{\circ 0} \mathrm{Co}$-labeled cyanocobalamin $\left({ }^{80} \mathrm{CoB}_{12}\right)$ to saturate all the vitamin $\mathrm{B}_{12}$ binding sites of the gastric juice. The specific activity of the ${ }^{\circ 0} \mathrm{CoB}_{12}$ was $0.1 \mathrm{mc} / \mathrm{mg}$. After incubation at room temperature, the gastric juice- $\mathrm{B}_{12}$ was ultrafiltered through Visking casing (Union Carbide Corp., Visking Div., Chicago, III.) to a volume of about $10 \mathrm{ml}$.

All procedures involved in purification, except radioactivity counting, were performed at $4^{\circ} \mathrm{C} .4 .0-\mathrm{ml}$ fractions were collected from each column directly into radioactivity counting tubes.

As the first purification step, the ultrafiltered sample was applied to a $1.8 \times 20 \mathrm{~cm}$ column of Amberlite CG-50 cation exchange resin of mesh size $200-400$. The resin was prepared 
by the method of Hirs, Moore, and Stein (5), equilibrated and packed in $0.05 \mathrm{M}$ sodium acetate buffer, $\mathrm{pH} 5.4$, and eluted with $0.58 \mathrm{~m}$ sodium acetate buffer, $\mathrm{pH}$ 5.4. Two protein-bound radioactivity peaks were consistently found, the first comprising about $10 \%$ of the total ${ }^{80} \mathrm{CoB}_{12}$-binding material. Since Chosy and Schilling (3) had previously shown that only the second of these two peaks has in vivo IF activity, $4.0-\mathrm{ml}$ fractions from this peak were pooled and ultrafiltered.

The second step in the purification process consisted of downward flow Sephadex G200 gel filtration using a $50 \times$ $3.8 \mathrm{~cm}$ column and $0.05 \mathrm{~m}$ sodium phosphate buffer, $\mathrm{pH}$ 7.5. A single protein-bound radioactivity peak was eluted in the albumin region from the ultrafiltered pooled fractions from the Amebrlite column. $4.0-\mathrm{ml}$ fractions from this peak were pooled and concentrated by ultrafiltration.

The final purification step was ion-exchange chromatography on a $1.8 \times 18 \mathrm{~cm}$ column of DEAE-cellulose prepared by cycling through $\mathrm{HCl}$ and $\mathrm{NaOH}$ and equilibrated in 0.02 M sodium phosphate buffer, $\mathrm{pH} 7.5$, at $4^{\circ} \mathrm{C}$. The concentrated sample obtained from gel filtration was allowed to enter the DEAE-cellulose column which was then washed with 40 $\mathrm{ml}$ of the equilibrating buffer. A gradient elution was applied to the column with rising molarity and falling $\mathrm{pH}$ from $0.02 \mathrm{~m}$ sodium phosphate buffer, $\mathrm{pH} 7.5$, to $0.2 \mathrm{M}$ sodium dihydrogen phosphate, $\mathrm{pH}$ 4.3. A single protein-bound radioactivity peak was eluted, and after removal of an aliquot for nitrogen determination (6), the final pooled sample was stored at $-20^{\circ} \mathrm{C}$ until used.

Radioiodination of human IF. The chloramine $\mathrm{T}$ method of Greenwood et al. (4) was used to label the purified $\mathrm{IF}_{-}{ }^{80} \mathrm{CoB}_{12}$ preparation $\left(\mathrm{IF}_{-}{ }^{80} \mathrm{CoB}_{12}\right)$ with radioiodine ${ }^{125} \mathrm{I}$. The appropriate quantity of chloramine $\mathrm{T}$ was selected by estimating the destructive effect of chloramine $T$ on the ${ }^{80} \mathrm{CoB}_{12}$ binding capacity of the purified IF. Concurrently, as a basis for comparison between the destructive effect of chloramine $\mathrm{T}$ on $\mathrm{IF}^{-{ }^{80}} \mathrm{CoB}_{12}$ and on crude dialyzed human gastric juice ${ }^{60} \mathrm{CoB}_{12}\left(\mathrm{GJ}_{-}{ }^{10} \mathrm{CoB}_{12}\right)$, equal concentrations of chloramine $\mathrm{T}$ solution were also added to $\mathrm{GJ}-{ }^{\infty} \mathrm{CoB}_{12}$. Equivalence of ${ }^{80} \mathrm{CoB}_{12}$ binding by the two preparations was obtained by dilution in saline of the more concentrated $I F-{ }^{80} \mathrm{CoB}_{12}$. As a result, both preparations bound $17 \mathrm{ng}{ }^{80} \mathrm{CoB}_{12} / \mathrm{ml}$, but the nitrogen content of the $\mathrm{GJ}-{ }^{80} \mathrm{CoB}_{12}$ was more than 300 times greater than that of $I F-{ }^{80} \mathrm{CoB}_{12}$.

Serial dilutions containing $80.0-0.009 \mathrm{mg} / \mathrm{ml}$ of chloramine $\mathrm{T}$ were then added in a final volume of $0.1 \mathrm{ml}$ solution to $1.0 \mathrm{ml}$ either of the $\mathrm{GJ}-{ }^{80} \mathrm{CoB}_{12}$ or of the $\mathrm{IF}^{60}{ }^{60} \mathrm{CoB}_{12}$ preparation. This mixture was incubated for $60 \mathrm{~min}$ at room temperature. To remove any free ${ }^{80} \mathrm{CoB}_{12}$ released by exposure to chloramine $T, 1.0 \mathrm{ml}$ of bovine serum albumincoated charcoal (7) was added to the mixture. After adsorption of free ${ }^{80} \mathrm{CoB}_{12}$, the charcoal was separated by centrifugation, and the supernate containing the remaining protein-bound ${ }^{80} \mathrm{CoB}_{12}$ was decanted. Radioactivity in the supernate was compared with that of $\mathrm{IF}^{-{ }^{\circ 0}} \mathrm{CoB}_{12}$ and $\mathrm{GJ}-{ }^{80} \mathrm{CoB}_{12}$ standards which had not been exposed to chloramine $T$. Table I shows per cent destruction of vitamin $B_{12}$ binding for each amount of chloramine $\mathrm{T}$ added. Release of ${ }^{80} \mathrm{Co}$ radioactivity from the $\mathrm{GJ}-{ }^{80} \mathrm{CoB}_{12}$ complex occurred only with amounts of chloramine $\mathrm{T}$ greater than $500 \mu \mathrm{g}$. In contrast, $125 \mu \mathrm{g}$ chloramine $\mathrm{T}$ was sufficient to destroy $14 \%$ of the ${ }^{80} \mathrm{CoB}_{12}$ binding of purified IF. This difference in chloramine $\mathrm{T}$ sensitivity of the two preparations may have been related to the difference in their protein concentration, but this possibility was not tested. because of the large quantities of purified material required for such an investigation.
TABLE I

Per cent Destruction of $B_{12}$ Binding*

\begin{tabular}{ccc}
\hline $\begin{array}{c}\text { Chloramine } \\
\text { T added }\end{array}$ & $\begin{array}{c}\text { Purified } \\
\text { IF-60 } \mathrm{CoB}_{12} \\
(0.135 \mu \mathrm{g} \mathrm{N})\end{array}$ & $\begin{array}{c}\text { Crude dialyzed } \\
\text { GJ-60 CoB } 12 \\
(44 \mu \mathrm{g} \mathrm{N})\end{array}$ \\
\hline$\mu g$ & $\%$ & $\%$ \\
8000 & $98 \pm 0.0$ & $92 \pm 5.0$ \\
4000 & $97 \pm 1.4$ & $85 \pm 1.4$ \\
1000 & $96 \pm 1.4$ & $25 \pm 11.3$ \\
500 & $73 \pm 13.5$ & $8 \pm 2.0$ \\
250 & $28 \pm 13.5$ & $2 \pm 5.4$ \\
125 & $14 \pm 10.6$ & $3 \pm 2.3$ \\
62.5 & $3 \pm 3.0$ & $3 \pm 3.0$ \\
31.2 & $7 \pm 3.6$ & $1 \pm 0.5$ \\
3.9 & $5 \pm 5.0$ & $1 \pm 1.4$ \\
0.9 & $2 \pm 2.2$ & $2 \pm 1.4$ \\
\hline
\end{tabular}

* Mean \pm SD of two experiments.

Since some denaturation of the IF might occur even with amounts of chloramine $\mathrm{T}$ insufficient to cause significant damage to ${ }^{80} \mathrm{CoB}_{12}$ binding, $31.2 \mu \mathrm{g}$ of chloramine $\mathrm{T}$, onefourth the amount that caused demonstrable destruction, was used for radioiodine labeling.

IF $-{ }^{80} \mathrm{CoB}_{12}$ containing $5-8 \mu \mathrm{g}$ nitrogen and $0.5 \mu \mathrm{g}{ }^{80} \mathrm{CoB}_{12}$ was thawed, transferred to a shortened disposable plastic counting tube, and diluted to $2.0 \mathrm{ml}$ with $0.05 \mathrm{~m}$ sodium phosphate buffer, $\mathrm{pH}$ 7.5. The tube was then sealed with a rubber cap and placed in a small lead pot in a hood. Through the rubber cap, $1.0 \mathrm{ml}$ of $\mathrm{NaI}$ solution containing from $5 \mu \mathrm{c}$ to $1.0 \mathrm{mc}{ }^{125} \mathrm{I}$ and $31.2 \mu \mathrm{g}$ of freshly prepared chloramine $\mathrm{T}$ in $0.1 \mathrm{ml}$ distilled water was then injected with a tuberculin syringe. $20 \mathrm{~min}$ later the reaction was stopped by the injection of $1.0 \mathrm{ml}$ of potassium metabisulphite $(96 \mathrm{mg} / \mathrm{ml})$ and $1.0 \mathrm{ml}$ potassium iodide $(800 \mathrm{mg} / \mathrm{ml})$. The lead pot containing the tube and reagents was shaken gently after each addition.

To separate the iodinated $I F-{ }^{80} \mathrm{CoB}_{12} \quad\left({ }^{125} \mathrm{I}-\mathrm{IF}^{80} \mathrm{CoB}_{12}\right)$ from the iodinating reagents, the contents of the tube were removed through the rubber cap with a long needle attached to a disposable syringe. The syringe was then emptied into a $2 \times 40 \mathrm{~cm}$ column of Sephadex G50 in bead form, packed in $0.05 \mathrm{~m}$ sodium phosphate buffer, $\mathrm{pH}$ 7.5. The sample was eluted with the same buffer at a flow rate of $40 \mathrm{ml} / \mathrm{hr}$. The distribution of ${ }^{125} \mathrm{I}$ radioactivity allowed easy identification of radioactivity appearing immediately after the void volume. This protein-bound radioactivity was consistently well separated from free ${ }^{125} \mathrm{I}$. The ${ }^{125} \mathrm{I}-\mathrm{IF}^{-}{ }^{00} \mathrm{CoB}_{12}$ was then pooled, ultrafiltered if necessary, and stored at $-20^{\circ} \mathrm{C}$ until use. To ensure complete removal of small amounts of free iodine, ${ }^{125} \mathrm{I}-\mathrm{IF}-{ }^{\mathrm{B}} \mathrm{CoB}_{12}$ was dialyzed against running tap water for $12 \mathrm{hr}$ immediately before use.

Evaluation of the effect of iodination on human intrinsic factor. Since the only difference between ${ }^{125} \mathrm{I}-\mathrm{IF}-{ }^{60} \mathrm{CoB}_{12}$ and $I F-{ }^{80} \mathrm{CoB}_{12}$ was the exposure of the former to the iodination reaction, the chromatographic, electrophoretic, antigenic, and absorption-promoting properties of the two preparations were compared to evaluate the effect of iodination of $\mathrm{IF}-{ }^{80} \mathrm{CoB}_{12}$.

DEAE-cellulose chromatography was performed by the method already described. Gel filtration was carried out using a reverse flow $2.0 \times 103 \mathrm{~cm}$ column of Sephadex G200. 
Vertical electrophoresis was performed in alkaline starch borate gel by the method of Smithies (8). Electrophoresis was carried out for $18 \mathrm{hr}$ at $130 \mathrm{v}$ either at room temperature or at $4^{\circ} \mathrm{C}$. The gel was then cut into $0.5 \mathrm{~cm}$ slices and assayed for radioactivity.

IF antibody serum was obtained from patients with adult type pernicious anemia (P.A.) established by the presence of histamine-fast achlorhydria and abnormal vitamin $B_{12}$ absorption which was corrected by human IF (9). Each serum was tested for antibody I or "blocking" activity by the charcoal test of Gottlieb, Lau, Wasserman, and Herbert (7) and for antibody II or "binding" activity by the antiglobulin coprecipitation technique of Taylor, Roitt, Doniach, Couchman, and Shapland (10) as well as by the electrophoretic retention test of Jeffries, Hoskins, and Sleisenger (11). P.A. sera containing IF antibody II (12) (AbII) precipitated $\mathrm{IF}^{-{ }^{80}} \mathrm{CoB}_{12}$ with antiglobulin serum and also caused retention of the $\mathrm{IF}-{ }^{80} \mathrm{CoB}_{12}$ at the origin of the starch gel. Although certain P.A. sera contained only AbI, sera with AbII activity always contained, in addition, AbI.

Reactions between ${ }^{125} \mathrm{I}-\mathrm{IF}{ }^{80}{ }^{80} \mathrm{CoB}_{12}$ and $\mathrm{AbII}$ were demonstrated by three techniques: (a) a modification of the antiglobulin coprecipitation technique of Taylor et al. described in detail by Schade, Abels, and Schilling (12), (b) the Sephadex G200 gel filtration method of Imrie and Schilling (13), and $(c)$ the electrophoretic retention test of Jeffries et al. (11). Reactions between ${ }^{125} \mathrm{I}-\mathrm{IF}_{-}{ }^{60} \mathrm{CoB}_{12}$ and AbI were demonstrated by incubating the ${ }^{125} \mathrm{I}-\mathrm{IF}-{ }^{80} \mathrm{CoB}_{12}$ for $24 \mathrm{hr}$ at $37^{\circ} \mathrm{C}$ with $\mathrm{AbI}$ to allow the AbI to exchange (14) with the ${ }^{80} \mathrm{CoB}_{12}$ bound to ${ }^{125} \mathrm{I}$-labeled IF. The same three techniques described above were then used to test for the ${ }^{125} \mathrm{I}-\mathrm{IF}$-AbI complex obtained by this prolonged incubation.

Rabbit anti-human globulin serum obtained from rabbits injected with ethanol-fractionated, DEAE-cellulose-separated, human gammaglobulin was kindly supplied by $\mathrm{H}$. L. Deutsch and R. L. Johnson.

The urine radioactivity test described by Schilling (9) was used to compare absorption of ${ }^{125} \mathrm{I}-\mathrm{IF}-{ }^{80} \mathrm{CoB}_{12}$ or IF${ }^{80} \mathrm{CoB}_{12}$ containing $0.5 \mu \mathrm{g}$ of ${ }^{80} \mathrm{CoB}_{12}$ in totally gastrectomized or pernicious anemia patients. When ${ }^{125} \mathrm{I}-\mathrm{IF}-{ }^{80} \mathrm{CoB}_{12}$ was used, subjects received Lugol's solution of iodine three drops t.i.d. for 3 days before and 7 days after the test to block thyroidal uptake of radioiodine. The dose of ${ }^{125} \mathrm{I}$ administered in these studies never exceeded $1.0 \mu \mathrm{c}$, and at least $50 \%$ of the ingested ${ }^{125} \mathrm{I}$ radioactivity was excreted in the urine within $24 \mathrm{hr}$. The tests were performed in the following sequence: free ${ }^{60} \mathrm{CoB}_{12}, \mathrm{IF}_{-}{ }^{80} \mathrm{CoB}_{12},{ }^{125} \mathrm{I}-\mathrm{IF}-{ }^{80} \mathrm{CoB}_{12}$. After the test with IF-bound ${ }^{10} \mathrm{CoB}_{12}$, two additional flushing doses of $1000 \mu \mathrm{g}$ nonradioactive cyanocobalamin were injected intramuscularly and urinary radioactivity was allowed to return to background before the second test with ${ }^{125} \mathrm{I}-\mathrm{IF}_{-}{ }^{80} \mathrm{CoB}_{12}$ was performed.

Urine radioactivity was determined by counting $500-\mathrm{ml}$ aliquots of urine in a well counter. All other radioactivity was assayed with a Autogamma detector (Packard Instrument Co., Inc., Downers Grove, I1l.) with one channel adjusted to count ${ }^{10} \mathrm{Co}$ radioactivity and another to count ${ }^{125} \mathrm{I}$ radioactivity. With this arrangement ${ }^{60} \mathrm{Co}$ counted approximately 1000 counts/nc above background and ${ }^{125} \mathrm{I}$ contributed to the ${ }^{80} \mathrm{Co}$ channel less than $0.05 \%$ of the counts detected in the ${ }^{125} \mathrm{I}$ channel. ${ }^{125} \mathrm{I}$ counted approximately 500 counts/nc above background and to this channel ${ }^{80} \mathrm{Co}$ contributed $5.3 \%$ of the counts detected in the ${ }^{80} \mathrm{Co}$ channel. To estimate ${ }^{125} \mathrm{I}$ radioactivity, counts attributable to ${ }^{80} \mathrm{Co}$ were subtracted from the total counts detected in the ${ }^{125} \mathrm{I}$ channel.

\section{RESULTS}

IF isolated from human gastric juice by ion-exchange chromatography and Dextran gel filtration bound $1.0 \mu \mathrm{g}$ ${ }^{80} \mathrm{CoB}_{12} / 10-16 \mu \mathrm{g}$ nitrogen. When compared to crude dialyzed gastric juice, this respresents nearly a 300 -fold increase in purity. These relatively pure IF preparations were consistently obtained in yields of $10-20 \%$. Iodination of the purified $\mathrm{IF}^{-{ }^{60}} \mathrm{CoB}_{12}$ preparation by the modification of the method of Greenwood et al. (4) resulted in ${ }^{125} \mathrm{I}-\mathrm{IF}-{ }^{80} \mathrm{CoB}_{12}$ preparations with specific activities from $0.4 \mu \mathrm{c}$ to $50 \mu \mathrm{c}{ }^{125} \mathrm{I} / \mu \mathrm{g}$ nitrogen. When fresh ${ }^{125} \mathrm{I}$-labeled $\mathrm{NaI}$ was used, $50 \%$ of the ${ }^{125} \mathrm{I}$ radioactivity added to the reaction mixture consistently became protein bound. On the other hand, when ${ }^{125} \mathrm{I}-\mathrm{NaI}$ that had decayed through two or more half-lives was used, as little as $2 \%$ of the added ${ }^{125} \mathrm{I}$ radioactivity became protein bound. The specific activity of the iodinated complex was directly related to the radioactivity of the iodinating reagents. Since virtually all of the ${ }^{80} \mathrm{Co}$ radioactivity present was eluted from the Sephadex G50 column in the protein peak, ${ }^{80} \mathrm{CoB}_{12}$ was not released from IF during iodination.

Column chromatography and starch-gel electrophoresis. Chromatography of ${ }^{125} \mathrm{I}-\mathrm{IF}_{-}{ }^{20} \mathrm{CoB}_{12}$ on DEAE-cellulose resulted in the elution of a major ${ }^{80} \mathrm{Co}$ radioactivity peak that was coincident with the major ${ }^{125} \mathrm{I}$ radioactivity peak (Fig. 1). Immediately following and incompletely separated from the major peak, a second small peak of coincident ${ }^{125} \mathrm{I}$ and ${ }^{80} \mathrm{Co}$ radioactivity was consistently found. With gel filtration on Sephadex G200

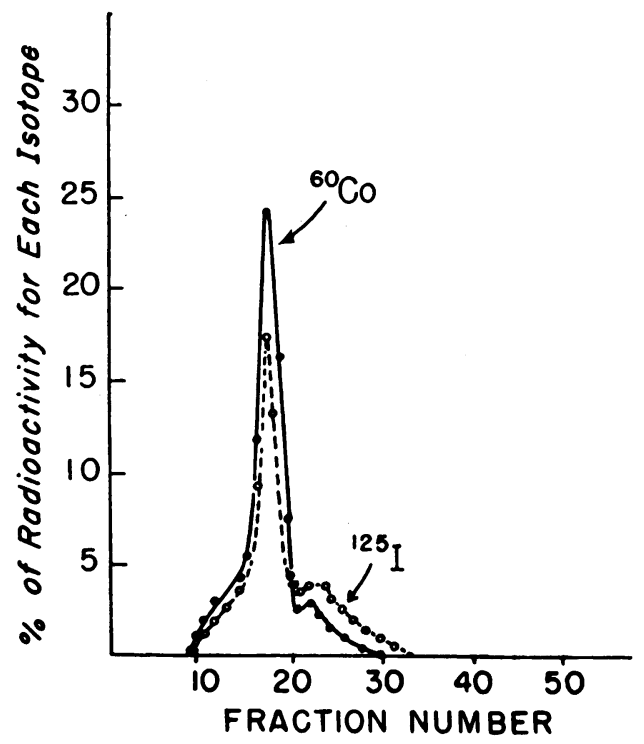

Figure 1 Fractionation of ${ }^{125} \mathrm{I}_{-} \mathrm{IF}^{-0}{ }^{00} \mathrm{CoB}_{12}$ on DEAE-cellulose. The major ${ }^{80} \mathrm{Co}$ radioactivity coincides with the major ${ }^{125} \mathrm{I}$ radioactivity peak. A small peak of coincident ${ }^{80} \mathrm{Co}$ and ${ }^{125}$ I radioactivity follows, and is incompletely separated from the major peak. 


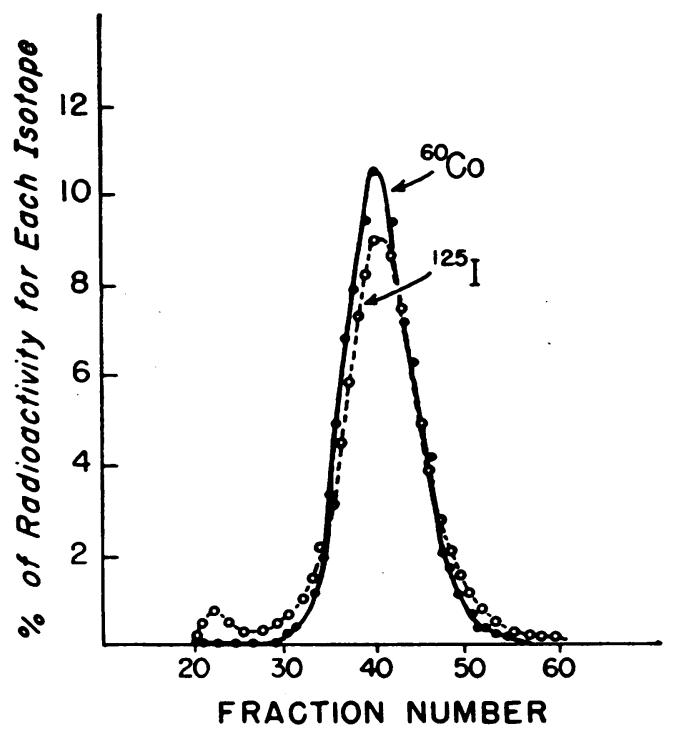

Figure 2 Fractionation of ${ }^{125} \mathrm{I}-\mathrm{IF}-{ }^{00} \mathrm{CoB}_{12}$ complex on Sephadex G200. The ${ }^{\infty 0} \mathrm{Co}$ radioactivity peak coincides with the major ${ }^{125} \mathrm{I}$ peak. A small ${ }^{125} \mathrm{I}$ radioactivity peak precedes, and is incompletely separated from, the major peak.

(Fig. 2), coincidence of a single ${ }^{80} \mathrm{Co}$ radioactivity peak with the major ${ }^{125} \mathrm{I}$ radioactivity peak was seen. With this separation a second smaller ${ }^{125} \mathrm{I}$ peak consistently preceded the major ${ }^{125} \mathrm{I}$ peak.

Simultaneous electrophoresis in starch gel of ${ }^{225} \mathrm{I}-\mathrm{IF}$ ${ }^{80} \mathrm{CoB}_{12}$ and $\mathrm{IF}_{-}{ }^{80} \mathrm{CoB}_{12}$ showed coincidence at the same anodal distance of the ${ }^{\circ 0} \mathrm{Co}$ radioactivity from both complexes (Fig. 3). Although considerable overlap occurred, the ${ }^{225} \mathrm{I}$ radioactivity peak from ${ }^{125} \mathrm{I}-\mathrm{IF}_{-}-{ }^{80} \mathrm{CoB}_{12}$ consistently migrated $0.5 \mathrm{~cm}$ further anodally than did the ${ }^{80} \mathrm{Co}$ radioactivity peak.

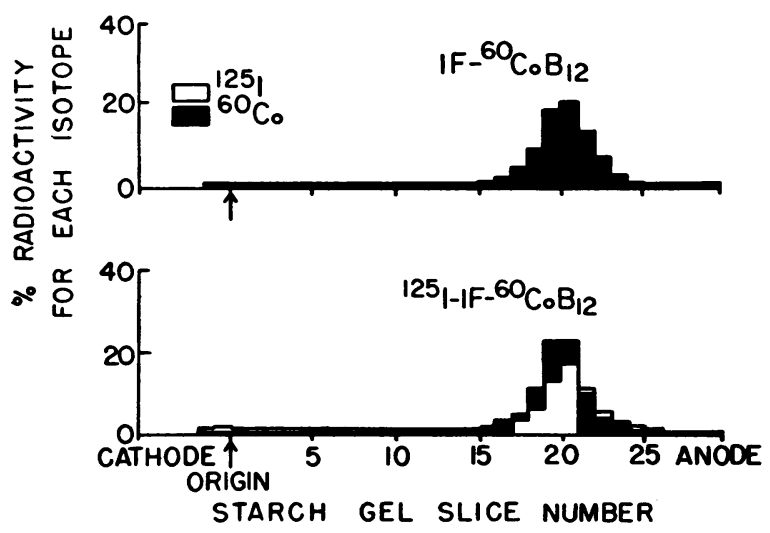

Figure 3 Vertical electrophoresis in alkaline starch borate gel for $18 \mathrm{hr}$ at $130 \mathrm{v}$. The ${ }^{60} \mathrm{Co}$ radioactivity peaks both from noniodinated $I F-{ }^{80} \mathrm{CoB}_{12}$ (above) and iodinated IF${ }^{60} \mathrm{CoB}_{12}$ (below) are coincident at the same anodal distance. The ${ }^{125}$ I radioactivity is seen one gel slice further towards the anode than the coincident ${ }^{\infty 0} \mathrm{Co}$ radioactivity.
Reactions with intrinsic factor antibody II. Incubation of either ${ }^{125} \mathrm{I}-\mathrm{IF}_{-}{ }^{60} \mathrm{CoB}_{12}$ or $\mathrm{IF}^{-00} \mathrm{CoB}_{12}$ with normal human serum resulted in precipitation of only a very small proportion of the ${ }^{80} \mathrm{Co}$ radioactivity from each complex when rabbit anti-human globulin serum (antiglobulin serum) was added (Table II). The percentage of ${ }^{125} \mathrm{I}$ radioactivity precipitated, however, was consistently somewhat greater. At present it is not at all clear why in the presence of normal serum, somewhat more ${ }^{105} \mathrm{I}$ radioactivity than ${ }^{60} \mathrm{Co}$ radioactivity should be precipitated by antiglobulin serum. When AbII was incubated with either ${ }^{125} \mathrm{I}-\mathrm{IF}_{-}{ }^{80} \mathrm{CoB}_{12}$ or $\mathrm{IF}_{-}{ }^{80} \mathrm{CoB}_{12}$, antiglobulin serum precipitated 20 times more ${ }^{\infty} \mathrm{Co}$ radioactivity from each preparation than after incubation with normal serum. Although the percentage of ${ }^{125} \mathrm{I}$ radioactivity precipitated by $\mathrm{AbII}$ and antiglobulin serum was only 4 -fold greater than with normal serum and antiglobulin serum, it was still consistently greater than $50 \%$ of the total ${ }^{125}$ I radioactivity present.

Gel filtration on Sephadex G200 of ${ }^{125} \mathrm{I}-\mathrm{IF}^{-00}{ }^{60} \mathrm{CoB}_{12}$ incubated with $\mathrm{AbII}$ consistently showed a strikingly different elution pattern from that obtained after incubation with normal human serum (Fig. 4). Whereas coincident ${ }^{90} \mathrm{Co}$ and major ${ }^{125} \mathrm{I}$ radioactivity peaks were eluted in the albumin region with normal serum (peak $B$, Fig. 4, above), after incubation with AbII, the major ${ }^{\infty 0} \mathrm{Co}$ and ${ }^{125} \mathrm{I}$ radioactivity peaks were instead eluted in the $19 \mathrm{~S}$ region (peak $A$, Fig. 4, below). Moreover, in the albumin region a small peak of ${ }^{125} \mathrm{I}$ radioactivity was eluted alone (peak B, Fig. 4, below) and in the third peak only ${ }^{\circ} \mathrm{Co}$ radioactivity was found (peak $C$, Fig. 4 , below). This third peak, which consisted of dialysable free ${ }^{00} \mathrm{CoB}_{12}$, was not seen after incubation of ${ }^{125} \mathrm{I}-\mathrm{IF}$ ${ }^{80} \mathrm{CoB}_{12}$ with normal serum.

TABLE II

Antigenic Activity of Iodinated Intrinsic Factor-Vitamin $B_{12}$ Complex towards IF Antibody II Serum

\begin{tabular}{|c|c|c|}
\hline & \multicolumn{2}{|c|}{$\begin{array}{l}\text { Per cent of total radioactivity of } \\
\text { each isotope precipitated by } \\
\text { antiglobulin serum* }\end{array}$} \\
\hline & $\%$ & $\%$ \\
\hline $\begin{array}{l}\text { Noniodinated IF- }{ }^{60} \mathrm{CoB}_{12} \\
\text { + normal serum }\end{array}$ & - & $3.0 \pm 1.5$ \\
\hline $\begin{array}{l}\text { Noniodinated IF }{ }^{60} \mathrm{CoB}_{12} \\
\quad+\text { IF antibody II serum }\end{array}$ & - & $58.4 \pm 6.8$ \\
\hline $\begin{array}{l}\text { Iodinated IF- }{ }^{60} \mathrm{CoB}_{12} \\
+ \text { normal serum }\end{array}$ & $13.3 \pm 1.9$ & $2.0 \pm 2.0$ \\
\hline $\begin{array}{l}\text { Iodinated IF-60 } \mathrm{CoB}_{12} \\
\quad+\text { IF antibody II serum }\end{array}$ & $52.8 \pm 1.4$ & $54.9 \pm 1.9$ \\
\hline
\end{tabular}

${ }^{*}$ Mean \pm SD of six experiments.

Radioiodination of Human Instrinsic Factor 


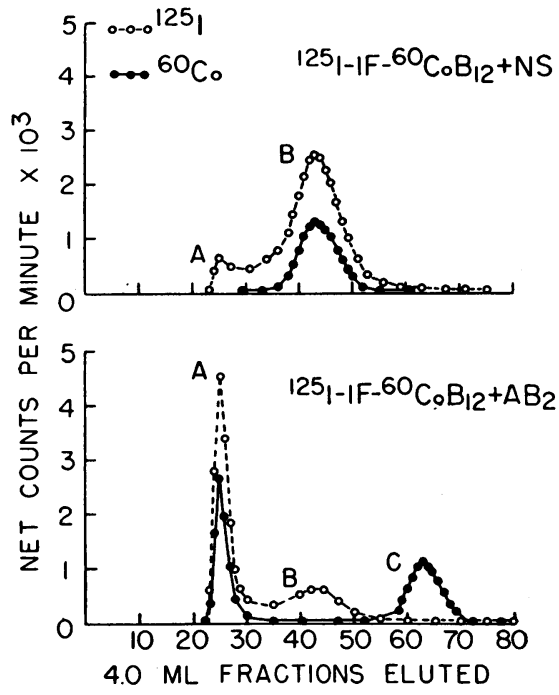

Figure 4 Elution pattern from Sephadex G200 of ${ }^{125} \mathrm{I}-\mathrm{IF}$ ${ }^{\infty} \mathrm{CoB}_{12}$ incubated with normal serum (NS, above) and IF antibody II (below). Coincidence of the major ${ }^{125} \mathrm{I}$ peak and the ${ }^{80} \mathrm{Co}$ peak in the region $B$ which contains serum albumin and a small ${ }^{125} \mathrm{I}$ peak $A$ in the $19 \mathrm{~S}$ region is seen after incubation with normal serum (above). After incubation with $\mathrm{AbII}$ the major coincident ${ }^{125} \mathrm{I}$ and ${ }^{80} \mathrm{Co}$ peak, $A$, is eluted in the $19 \mathrm{~S}$ region (below). A small ${ }^{125} \mathrm{I}$ peak, $B$, is eluted in the albumin region without coincident ${ }^{\circ 0} \mathrm{Co}$ radioactivity and a small ${ }^{00} \mathrm{Co}$ peak, $C$, without coincident ${ }^{125} \mathrm{I}$ is seen in the small molecular region.

Incubation of ${ }^{125} \mathrm{I}-\mathrm{IF}-{ }^{80} \mathrm{CoB}_{12}$ with $\mathrm{AbII}$ serum abolished the anodal electrophoretic migration both of ${ }^{125} \mathrm{I}$ and ${ }^{80} \mathrm{Co}$ radioactivity (Fig. 5, below) that was seen after incubation with normal serum (Fig. 5, above). Cathodal migration of ${ }^{\infty 0} \mathrm{Co}$ radioactivity similar to that observed $(12,14)$ during electrophoresis of free ${ }^{80} \mathrm{CoB}_{12}$ was seen only after incubation of ${ }^{125} \mathrm{I}-\mathrm{IF}^{-80}{ }^{80} \mathrm{CoB}_{12}$ with AbII.

Reactions with intrinsic factor antibody I. Only small amounts of ${ }^{125} \mathrm{I}$ radioactivity were precipitated by antiglobulin serum immediately after mixing ${ }^{125} \mathrm{I}-\mathrm{IF}$ ${ }^{80} \mathrm{CoB}_{12}$ either with normal serum or with $\mathrm{AbI}$ serum (Table III). Incubation of ${ }^{125} \mathrm{I}-\mathrm{IF}{ }_{-}{ }^{80} \mathrm{CoB}_{12}$ with normal serum for $24 \mathrm{hr}$ at $37^{\circ} \mathrm{C}$ produced no change in the ${ }^{125} \mathrm{I}$ radioactivity precipitated by antiglobulin serum. However, incubation of ${ }^{125} \mathrm{I}-\mathrm{IF}-{ }^{-0} \mathrm{CoB}_{12}$ with $\mathrm{AbI}$ for $24 \mathrm{hr}$ at $37^{\circ} \mathrm{C}$ consistently resulted in a marked increase in the ${ }^{125} \mathrm{I}$ radioactivity precipitated. This increase was similar to the precipitation observed when antiglobulin serum was added after $\mathrm{AbII}$ was mixed with ${ }^{125} \mathrm{I}-\mathrm{IF}-{ }^{80} \mathrm{CoB}_{12}$.

Gel filtration on Sepadex G200 immediately after mixing ${ }^{125} \mathrm{I}-\mathrm{IF}-{ }^{\mathrm{e}} \mathrm{CoB}_{12}$ with $\mathrm{AbI}$ resulted in the same elution pattern as was seen after mixing with normal serum (Figs. 4, above, and 6, above). After incubation with AbII for $24 \mathrm{hr},{ }^{125} \mathrm{I}$ and ${ }^{80} \mathrm{Co}$ radioactivity peaks were eluted together in the $19 \mathrm{~S}$ region (peak $A$, Fig. 4, below). After incubation with AbI, however, the $19 \mathrm{~S}$ region (peak $A$, Fig. 6 , below) contained only ${ }^{125}$ I radioactivity. The effects of AbII and AbI differed in another important respect. When ${ }^{125} \mathrm{I}-\mathrm{IF}_{-}{ }^{80} \mathrm{CoB}_{12}$ was incubated with $\mathrm{AbII}$ and subjected to gel filtration the albumin region (peak $B$, Fig. 4 , below) contained ${ }^{125} \mathrm{I}$ radioactivity only. When $\mathrm{AbI}$ was used, however, the albumin region (peak $B$, Fig. 6 below) contained coincident ${ }^{\circ 0} \mathrm{Co}$ and ${ }^{125} \mathrm{I}$ radioactivity. In both instances, however, the third peak (peak $C$, Figs. 4, below, and 6, below) contained only ${ }^{\infty} \mathrm{Co}$ radioactivity.

Starch-gel electrophoresis of ${ }^{125} \mathrm{I}-\mathrm{IF}-{ }^{-00} \mathrm{CoB}_{12}$ immediately after the addition of AbI (Fig. 7, above) showed the same migration of the ${ }^{80} \mathrm{Co}$ and ${ }^{125} \mathrm{I}$ radioactivity towards the anode as was observed when ${ }^{125} \mathrm{I}-\mathrm{IF}_{-}{ }^{60} \mathrm{CoBB}_{13}$ was mixed with normal serum (Fig. 5, above). In addition a small peak of ${ }^{125} \mathrm{I}$ radioactivity was usually retained at the origin, and a small peak of ${ }^{80} \mathrm{Co}$ radioactivity consistently migrated towards the cathode. On

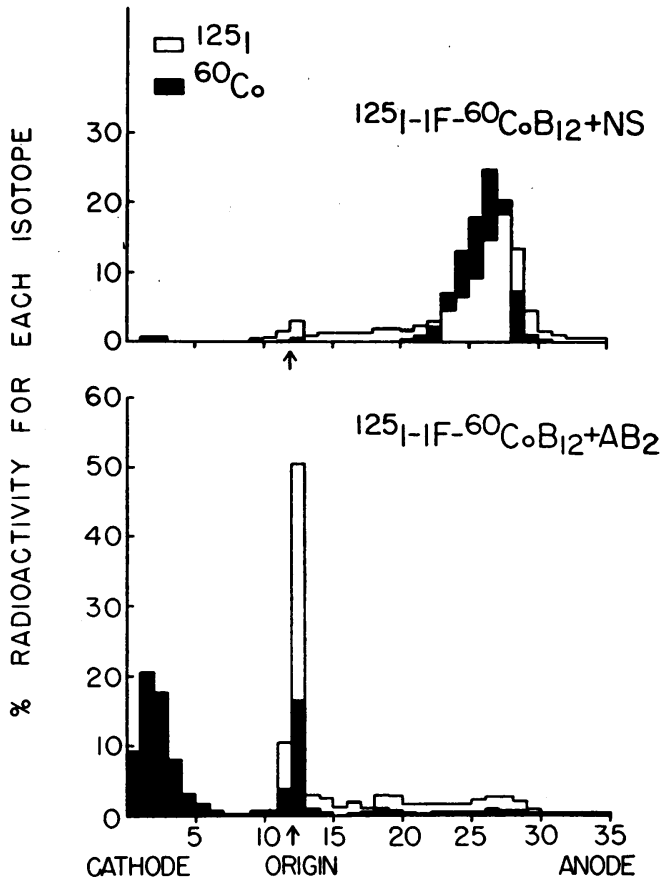

STARCH GEL SLICE NUMBER

FIGURE 5 Vertical electrophoresis in alkaline starch borategel of ${ }^{125} \mathrm{I}-\mathrm{IF}_{-}{ }^{80} \mathrm{CoB}_{12}$ incubated with normal serum (above) and with IF antibody II (below). The black bars show the per cent of total ${ }^{80} \mathrm{Co}$ radioactivity and the open bars the per cent of total ${ }^{125} \mathrm{I}$ radioactivity in each gel slice. The anodal migration of ${ }^{125} \mathrm{I}$ and ${ }^{80} \mathrm{Co}$ radioactivity peaks seen after incubation with normal serum (above) is abolished after incubation with IF antibody II (below). In addition a peak of ${ }^{\circ 0} \mathrm{Co}$ radioactivity migrating towards the cathode is seen after IF antibody II incubation. 
TABLE III

Antigenic Activity of Iodinated Intrinsic Factor-Vitamin $B_{12}$ Complex towards IF Antibody I Serum

\begin{tabular}{ccc}
\hline & $\begin{array}{c}\text { Per cent of total }{ }^{125} \text { I radioactivity } \\
\text { precipitated by antiglobulin } \\
\text { serum* added: }\end{array}$ \\
\cline { 2 - 3 } & $\begin{array}{c}\text { After } 24 \mathrm{hr} \\
\text { incubation }\end{array}$ \\
\hline $\begin{array}{c}\text { Immediately } \\
\quad+\text { normal serum } \\
\begin{array}{c}\text { Iodinated IF-B } \\
\text { + IF antibody I }\end{array}\end{array}$ & $10.5 \pm 3.2$ & $16.3 \pm 1.7$ \\
$\begin{array}{c}\text { Iodinated IF-B } \\
+ \text { IF antibody II }\end{array}$ & $16.1 \pm 4.1$ & $53.7 \pm 8.7$ \\
$\quad$ & $51.1 \pm 6.2$ & $51.9 \pm 5.5$ \\
\hline
\end{tabular}

* Mean \pm SD of four experiments.

the other hand, incubation of ${ }^{125} \mathrm{I}-\mathrm{IF}^{-80} \mathrm{CoB}_{12}$ for $24 \mathrm{hr}$ at $37^{\circ} \mathrm{C}$ with $\mathrm{AbI}$ resulted in an electrophoretic pattern (Fig. 7, below) different from that obtained after similar incubation with either normal serum or AbII (Fig. 5 , above and below). Whereas incubation with AbII abolished anodal electrophoretic migration of ${ }^{60} \mathrm{Co}$ and

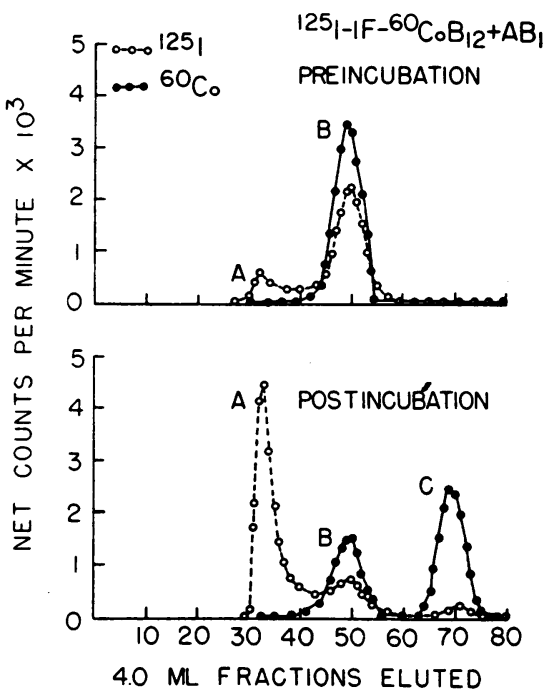

Figure 6 Elution pattern from Sephadex G200 of ${ }^{125}$ I-IF${ }^{\infty 0} \mathrm{CoB}_{12}$ immediately after exposure to IF antibody I (above, preincubation) and after $24 \mathrm{hr}$ incubation at $37^{\circ}$ with IF antibody I (below, postincubation). As shown above, the elution pattern after immediate incubation (preincubation) with IF antibody I is similar to that seen after incubation with normal serum. $24 \mathrm{hr}$ incubation with IF antibody I results in a different pattern from that observed both after incubation with normal serum and IF antibody II. As shown below, in the $19 \mathrm{~S}$ region a single ${ }^{125} \mathrm{I}$ peak $(A)$ without coincident ${ }^{60} \mathrm{Co}$ is eluted. In the albumin region a small coincident peak $(B)$ of ${ }^{125} \mathrm{I}$ and ${ }^{80} \mathrm{Co}$ is seen. In peak $C$, the small molecular region, only ${ }^{80} \mathrm{Co}$ is found.
${ }^{125} \mathrm{I}$ radioactivity, incubation with $\mathrm{AbI}$ resulted in the anodal migration of two ${ }^{125} \mathrm{I}$ peaks (Fig. 7, below). The first of these contained only ${ }^{125} \mathrm{I}$ radioactivity and moved only a short distance into the gel; the second contained both ${ }^{80} \mathrm{Co}$ and ${ }^{125} \mathrm{I}$ radioactivity and migrated to the same anodal distance as was observed during electrophoresis immediately after $\mathrm{AbI}$ had been mixed with ${ }^{205} \mathrm{I}-\mathrm{IF}-{ }^{80} \mathrm{CoB}_{12}$. After the $24 \mathrm{hr}$ incubation with $\mathrm{AbI}$, the cathodally migrating ${ }^{\infty} \mathrm{Co}$ radioactivity peak consisting of free ${ }^{60} \mathrm{CoB}_{12}$ increased greatly.

In vivo activity. Urinary excretion of ${ }^{\circ} \mathrm{Co}$ radioac.. tivity after oral administration of purified but noniodinated $\mathrm{IF}_{-}{ }^{00} \mathrm{CoB}_{12}$ to patients with pernicious anemia or total gastrectomy was consistently greater than after free ${ }^{\infty} \mathrm{CoB}_{12}$ (Table IV). Enhancement of ${ }^{\circ 0} \mathrm{Co}$ urinary radioactivity excretion was also seen after the oral administration of ${ }^{125} \mathrm{I}-\mathrm{IF}-{ }^{60} \mathrm{CoB}_{12}$. With freshly prepared ${ }^{125} \mathrm{I}-\mathrm{IF}-{ }^{80} \mathrm{CoB}_{12}$, the urinary excretion of ${ }^{80} \mathrm{Co}$ was not significantly different from that observed with noniodinated $\mathrm{IF}_{-}{ }^{\infty} \mathrm{CoB}_{12}$. After storage for $1-2$ months, however, the urinary ${ }^{80} \mathrm{Co}$ excretion after ${ }^{125} \mathrm{I}-\mathrm{IF}_{-}{ }^{80} \mathrm{CoB}_{12}$ fell to less than half of that obtained with noniodinated

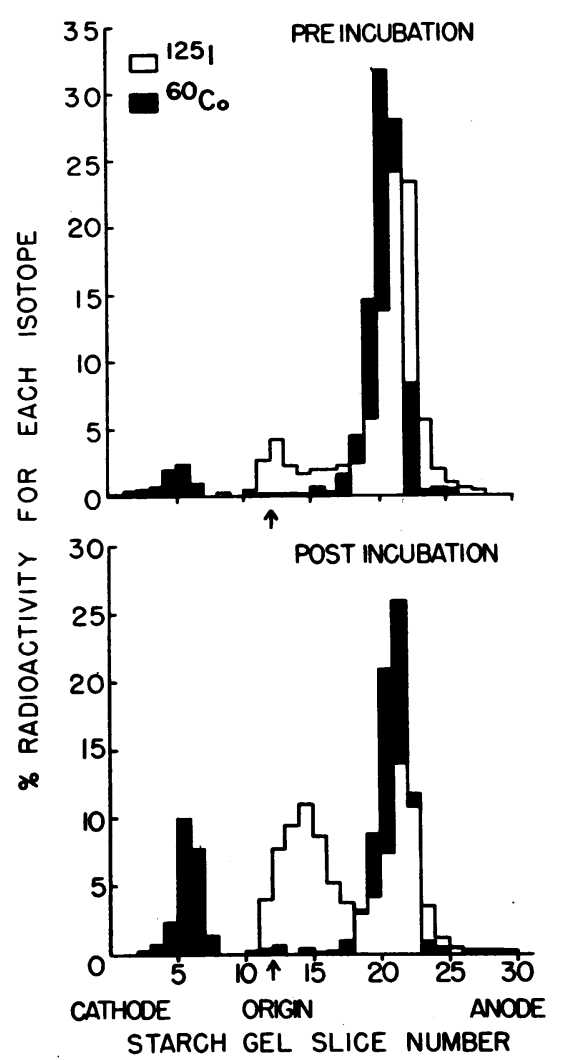

FIGURE 7 Vertical electrophoresis in alkaline starch borategel at $4^{\circ} \mathrm{C}$ of ${ }^{125} \mathrm{I}-\mathrm{IF}-{ }^{80} \mathrm{CoB}_{12}$ immediately after exposure to AbI (above, preincubation) and after $24 \mathrm{hr}$ incubation at $37^{\circ} \mathrm{C}$ with $\mathrm{AbI}$ (below, postincubation).

Radioiodination of Human Instrinsic Factor 
TABLE IV

In vivo Activity of Iodinated Intrinsic

Factor-Vitamin $B_{12}$

Complex

\begin{tabular}{crrccc}
\hline \multicolumn{1}{c}{ Subject } & H. E. & A. R. & E. C. & B. R. & E. K. \\
\hline $0.5 \mu$ g Co $^{60} \mathrm{~B}_{12}$ & 1.1 & 0.7 & 0.6 & 1.8 & 0.5 \\
$\begin{array}{c}0.5 \mu \mathrm{g} \mathrm{Co}^{60} \mathrm{~B}_{12}- \\
\text { noniodinated IF }\end{array}$ & 13.0 & 21.1 & 9.5 & $16.8^{*}$ & $12.6 \ddagger$ \\
$\begin{array}{c}0.5 \mu \mathrm{g} \mathrm{Co}^{60} \mathrm{~B}_{12-} \\
\text { iodinated IF }\end{array}$ & 15.0 & 14.5 & 7.4 & $6.0^{*}$ & $6.2 \ddagger$ \\
\hline
\end{tabular}

All values expressed in terms of per cent of oral dose excreted in the urine in $24 \mathrm{hr}$.

* IF preparations stored for 1 month at $-20^{\circ} \mathrm{C}$.

$\ddagger$ IF preparations stored for 2 months at $-20^{\circ} \mathrm{C}$.

$I F-{ }^{80} \mathrm{CoB}_{12}$ in the two trials performed. Nevertheless, excretion was still greater than that observed after free ${ }^{\circ 0} \mathrm{CoB}_{12}$. Nonetheless, simultaneous electrophoresis of these stored preparations of ${ }^{125} \mathrm{I}-\mathrm{IF}-{ }^{60} \mathrm{CoB}_{12}$ and $\mathrm{IF}_{-}{ }^{80} \mathrm{CoB}_{12}$ incubated both with normal serum and with AbII demonstrated no change in their electrophoretic or antigenic properties.

\section{DISCUSSION}

Radioiodination of $\mathrm{IF}^{60}{ }^{60} \mathrm{CoB}_{12}$ consistently resulted in preparations of ${ }^{125} \mathrm{I}-\mathrm{IF}_{-}{ }^{00} \mathrm{CoB}_{12}$ which contained readily measureable quantities of ${ }^{125} \mathrm{I}$ radioactivity. Vitamin $\mathrm{B}_{12}$ was not released from the $\mathrm{IF}^{-10} \mathrm{CoB}_{12}$ complex during iodination. Although the vitamin $\mathrm{B}_{12}$-binding activity of the IF was thus apparently not damaged by the procedure, it was important to determine that other characteristics of the IF molecule had not been altered since many macromolecular substances are able to bind vitamin $B_{12}$, but unlike IF, do not enhance vitamin $B_{12} a b-$ sorption by the distal small intestine (16) and presumably do not exhibit antigenicity to IF antibody. Since the affinity of vitamin $B_{12}$ for IF (17) differs markedly from the affinity of IF-B $B_{12}$ complex for the intestinal cell surface (18), it is likely that at least two distinct active binding sites are present on the IF molecule: $(a)$ a vitamin $B_{12}$ binding site present in IF as well as other macromolecules and $(b)$ an ileal mucosal receptor binding site and antibody binding sites which are unique to IF. Because of their apparently distinct nature, integrity of one does not necessarily mean integrity of the others. It was therefore essential to determine the effect of the iodination process on the unique antigenic and biologic properties of IF, despite the fact that the vitamin $\mathrm{B}_{12}$ binding activity of IF was not impaired.

The coincidence of the ${ }^{80} \mathrm{Co}$ radioactivity peak with the major ${ }^{125} \mathrm{I}$ radioactivity peak both on DEAE-cellulose and Sephadex G200 indicates that iodination of IF $-{ }^{80} \mathrm{CoB}_{12}$ occurs without significant damage to its chro- matographic or gel filtration characteristics. Furthermore, the coincidence at the same anodal distance of the ${ }^{80} \mathrm{Co}$ radioactivity peaks from iodinated and noniodinated $\mathrm{IF}_{-}{ }^{80} \mathrm{CoB}_{12}$ after electrophoresis on starch gel demonstrates the absence of damage to the electrophoretic characteristics of $\mathrm{IF}_{-}{ }^{80} \mathrm{CoB}_{12}$. During electrophoresis, however, there was a consistent though very slight difference in the migration of ${ }^{80} \mathrm{Co}$ and the ${ }^{125} \mathrm{I}$ radioactivity from iodinated $\mathrm{IF}_{-}{ }^{80} \mathrm{CoB}_{12}$. Further investigations are necessary to explain this observation.

The chromatographic and electrophoretic behavior of iodinated $\mathrm{IF}-{ }^{80} \mathrm{CoB}_{12}$ provides a means of testing the effect of iodination on the antigenicity of $\mathrm{IF}^{-60} \mathrm{CoB}_{12}$. For this purpose one can use the antibody that binds the $\mathrm{IF}_{-}{ }^{60} \mathrm{CoB}_{12}$ complex ( $\mathrm{AbII}$ ) as well as the antibody that blocks $\mathrm{B}_{12}$ binding by IF $(\mathrm{AbI})$. The serum used as the source of AbII activity in these studies always contained AbI activity in addition to AbII activity. The AbI serum used, however, contained only AbI activity.

Several findings indicate that antigenicity of $\mathrm{IF}^{-{ }^{80}} \mathrm{CoB}_{12}$ is not altered by the iodination procedure: $(a)$ the similar precipitation of ${ }^{80} \mathrm{Co}$ radioactivity from iodinated and noniodinated $\mathrm{IF}^{60}{ }^{60} \mathrm{CoB}_{12}$ by $\mathrm{AbII}$ and antiglobulin serum (Table II), (b) the transfer of the major ${ }^{80} \mathrm{Co}$ radioactivity peak on Sephadex G200 from the albumin region with normal serum to the $19 \mathrm{~S}$ region after AbII was mixed with iodinated $\mathrm{IF}^{-{ }^{80}} \mathrm{CoB}_{12}$ (Fig. 4, above and below), and ( $c$ ) the abolition by AbII of the anodal electrophoretic migration of ${ }^{80} \mathrm{Co}$ radioactivity both from iodinated (Fig. 5, above and below) and noniodinated IF $-{ }^{60} \mathrm{CoB}_{12}$. In addition, several observations suggest that ${ }^{125} \mathrm{I}$ radioactivity is attached to the $I F$-vitamin $B_{12}$ complex rather than to any contaminating substances: (a) the ${ }^{125} \mathrm{I}$ radioactivity precipitated by antiglobulin serum from iodinated $\mathrm{IF}_{-}{ }^{80} \mathrm{CoB}_{12}$ incubated with $\mathrm{AbII}$ is four times greater than that precipitated after incubation with normal serum (Table II, (b) the ${ }^{125} \mathrm{I}$ and ${ }^{60} \mathrm{Co}$ radioactivity eluted from Sephadex G200 coincided in the albumin region when iodinated $\mathrm{IF}^{-60} \mathrm{CoB}_{12}$ was incubated with normal serum and in the $19 \mathrm{~S}$ region when incubated with AbII (Fig. 4, above and below), and ( $c$ ) anodal electrophoretic migration both of ${ }^{60} \mathrm{Co}$ and ${ }^{125} \mathrm{I}$ radioactivity from iodinated $\mathrm{IF}^{-{ }^{80}} \mathrm{CoB}_{12}$ was abolished by incubating with AbII (Fig. 5, below).

The consistent appearance of cathodally migrating ${ }^{60} \mathrm{Co}$ radioactivity seen on starch-gel electrophoresis (Fig. 5) when iodinated $\mathrm{IF}_{-}{ }^{\infty} \mathrm{CoB}_{12}$ was mixed with AbII serum suggests that this serum, which has both $\mathrm{AbI}$ and $\mathrm{AbII}$ activity, has an effect in freeing ${ }^{60} \mathrm{CoB}_{12}$ from its binding to IF. This effect of AbII serum was also seen during gel filtration on Sephadex G200. Free ${ }^{\circ 0} \mathrm{CoB}_{12}$ was eluted in the small molecular region (Fig. 4). On the other hand, release of ${ }^{80} \mathrm{CoB}_{12}$ from IF by serum that contains AbI activity alone occurs only after prolonged incubation (Table III, Fig. 6, above and below, 
Fig. 7, above and below). Since release by $\mathrm{AbI}$ requires prolonged incubation (14) and since ${ }^{\circ 0} \mathrm{CoB}_{12}$ was released shortly after $I F-{ }^{\infty 0} \mathrm{CoB}_{12}$ was mixed with $\mathrm{AbII}$ serum, it is possible that this release was an effect of the AbII activity rather than any $\mathrm{AbI}$ activity present in the AbII serum. On the other hand, since AbII sera tend to contain high titers of $\mathrm{AbI}$, the observed rapid release might have resulted from the presence of these high titers. To distinguish unequivocally release due to $\mathrm{AbI}$ from that due to AbII, serum containing AbII alone would be required, but this type of IF antibody is found very rarely in pernicious anemia patients.

One might expect that when an antiglobulin coprecipitation test was performed with purified $\mathrm{IF}_{-}{ }^{\infty} \mathrm{CoB}_{12}$ and AbII serum, all or nearly all of the IF-bound ${ }^{80} \mathrm{Co}$ radioactivity would have been precipitated. Instead, the amount of ${ }^{60} \mathrm{CoB}_{12}$ bound to purified IF, precipitated (Table II), was similar to that found by other workers using radioactive vitamin $B_{12}$ bound to crude gastric juice (10). Crude gastric juice contains, in addition to IF, non-IF vitamin $B_{12}$-binding macromolecules that presumably are not antigenic to AbII and thus are not precipitated by the addition of $\mathrm{AbII}$ and antiglobulin serum. Purified $I F-{ }^{80} \mathrm{CoB}_{12}$ does not contain these non-IF vitamin $\mathrm{B}_{12}$-binding macromolecules (15) so that the presence of nonantigenic vitamin $\mathrm{B}_{12}$ binders in the supernate after antiglobulin precipitation cannot account for the unprecipitated vitamin $B_{12}$ radioactivity. The fact that some ${ }^{80} \mathrm{CoB}_{12}$ is released from the $\mathrm{IF}^{60} \mathrm{CoB}_{12}$ complex in the presence of AbII serum may explain why in the test performed with relatively pure $\mathrm{IF}_{-}{ }^{80} \mathrm{CoB}_{12}$ all of the ${ }^{80} \mathrm{CoB}_{12}$ was not precipitated by $\mathrm{AbII}$ and antiglobulin serum. Unfortunately, the amounts of radioactivity used in these experiments were insufficient to determine accurately whether this unprecipitated ${ }^{80} \mathrm{CoB}_{12}$ was in fact free vitamin which had been released from IF.

The results of gel filtration and electrophoresis studies indicated that prolonged incubation of $\mathrm{AbI}$ with ${ }^{125} \mathrm{I}-\mathrm{IF}_{-}{ }^{60} \mathrm{CoB}_{12}$ resulted in an exchange of $\mathrm{AbI}$ for ${ }^{80} \mathrm{CoB}_{12}$ on ${ }^{120} \mathrm{I}-\mathrm{IF}$. As a result of this exchange free ${ }^{80} \mathrm{CoB}_{12}$ was released and ${ }^{125} \mathrm{I}-\mathrm{IF}-\mathrm{AbI}$ complex was formed. Several observations support the occurrence of this exchange and indicate that the ${ }^{125} \mathrm{I}$ radioactivity was attached to IF rather than to cyanocobalamin: (a) after exchange a 4-fold greater precipitation of ${ }^{125} \mathrm{I}$ radioactivity occurred when antiglobulin serum was added to the reactants than occurred before exchange (Table III); $(b)$ ${ }^{125}$ I radioactivity was eluted from Sephadex G200 as a peak in the albumin region coincident with ${ }^{80} \mathrm{Co}$ radioactivity (Figs. 4 above, and 6 above), and after exchange, as a single peak in the $19 \mathrm{~S}$ region without coincident ${ }^{60} \mathrm{Co}$ radioactivity (Fig. 6, below); and (c) only after exchange were two anodally migrating peaks of ${ }^{125} \mathrm{I}$ radioactivity, one of which was associated with
${ }^{80} \mathrm{Co}$ radioactivity, consistently seen on starch-gel electrophoresis (Fig. 7, below).

The results of gel filtration and electrophoresis after prolonged incubation of ${ }^{125} \mathrm{I}-\mathrm{IF}_{-}{ }^{80} \mathrm{CoB}_{12}$ with $\mathrm{AbI}$ are best explained on the basis of an equilibrium (14) between ${ }^{125} \mathrm{I}-\mathrm{IF}-\mathrm{AbI}$ and ${ }^{125} \mathrm{I}-\mathrm{IF}-{ }^{80} \mathrm{CoB}_{12}$. The ${ }^{125} \mathrm{I}-\mathrm{IF}-\mathrm{AbI}$ is eluted in the $19 \mathrm{~S}$ region on Sephadex G200 (peak $B$, Fig. 4, below) and migrates a short distance into the gel on starch-gel electrophoresis (Fig. 7, below). The ${ }^{125} \mathrm{I}-\mathrm{IF}-{ }^{80} \mathrm{CoB}_{12}$ is eluted in the albumin region on Sephadex G200 (peak B, Fig. 6, below) and migrates into the starch gel to the same anodal distance as noniodinated IF $-{ }^{80} \mathrm{CoB}_{12}$ (Fig. 7, below). The free ${ }^{80} \mathrm{CoB}_{12}$ displaced by $\mathrm{AbI}$ appears in the third radioactivity peak from Sephadex G200 (peak $C$, Fig. 4, below) and migrates cathodally in the starch gel (Fig. 7, below). The equilibrium reaction may be written as follows:

$$
\begin{aligned}
& \underset{{ }^{125} \mathrm{I}-\mathrm{IF}-{ }^{60} \mathrm{CoB}_{12} \rightleftarrows{ }^{125} \mathrm{I}-\mathrm{IF}+{ }^{60} \mathrm{CoB}_{12}}{+} \\
& \downarrow \uparrow \\
& { }^{125} \text { I-IF-AbI }
\end{aligned}
$$

These studies provide additional evidence that $\mathrm{AbI}$ and AbII are distinct entities as proposed by Schade, Feick, Imrie, and Schilling (14). In contrast to AbII which precipitated similar percentages of ${ }^{80} \mathrm{Co}$ and ${ }^{125} \mathrm{I}$ radioactivity from iodinated $I F-{ }^{80} \mathrm{CoB}_{12}$ in the presence of antiglobulin serum, $\mathrm{AbI}$ precipitated no ${ }^{80} \mathrm{Co}$ radioactivity and ${ }^{125} \mathrm{I}$ radioactivity only after exchange had taken place (Table III). Furthermore, AbII shifted the coincident ${ }^{125} \mathrm{I}$ and ${ }^{80} \mathrm{Co}$ radioactivity peak obtained in the albumin region on gel filtration of iodinated IF${ }^{\infty 0} \mathrm{CoB}_{12}$ (Figs. 2, 4, and 6 above) to another coincident peak in the $19 \mathrm{~S}$ region (Fig. 4, below), while AbI moved only the ${ }^{125} \mathrm{I}$ radioactivity peak to the $19 \mathrm{~S}$ region (Fig. 6, above). Finally, AbII blocked anodal electrophoretic migration of ${ }^{125} \mathrm{I}$ as well as ${ }^{60} \mathrm{Co}$ radioactivity (Fig. 5, below), and $\mathrm{AbI}$ after exchange resulted in two anodally migrating ${ }^{125} \mathrm{I}$ radioactivity peaks, only one of which was associated with ${ }^{80} \mathrm{Co}$ radioactivity (Fig. 7, below).

The results of this study indicate that the iodinated complex is not entirely homogeneous. Iodination of nitrogen-containing impurities and/or aggregation and denaturation of some IF molecules that are still bound to ${ }^{80} \mathrm{CoB}_{12}$ during the iodination process may explain the small but persistent ${ }^{125} \mathrm{I}$ radioactivity peaks eluted without coincident ${ }^{\circ 0} \mathrm{Co}$ radioactivity from Sephadex G200 (Fig. 2, above, and 6, above) and with coincident (Figs. 2, 4, above, and 6, above) and with coincident ${ }^{\circ} \mathrm{Co}$ radioactivity from DEAE-cellulose (Fig. 1 ). The incomplete transfer of ${ }^{125} \mathrm{I}$ radioactivity from the albumin region to the $19 \mathrm{~S}$ region on Sephadex G200 by AbII

Radioiodination of Human Instrinsic Factor 523 
(Fig. 4) also suggests that either iodinated protein is present as a contaminant or that some IF molecules have been altered and have lost antigenic activity. Nevertheless, the weight of evidence from studies with three complementary techniques using two distinct IF antibodies indicates that the predominant ${ }^{125} \mathrm{I}$-labeled molecule in this heterogenous mixture is in fact IF.

The in vivo trials of iodinated $\mathrm{IF}_{-}{ }^{80} \mathrm{CoB}_{12}$ tested the absorption-promoting activity of IF. The three studies with freshly prepared material suggest that the iodination procedure did not alter the $\mathrm{IF}_{-}{ }^{80} \mathrm{CoB}_{12}$ complex from its readily absorbable form. Absorption was decreased, however, after prolonged storage although no alteration in antigenicity to AbII could be demonstrated by starchgel electrophoresis. Nonetheless, absorption was still greater than after the administration of free ${ }^{\infty} \mathrm{CoB}_{12}$.

\section{ACKNOWLEDGMENTS}

We acknowledge the excellent technical assistance of Miss Mary Muckerheide and Miss Patricia Feick.

This work was supported in part by Grants AM 12980 and AM 11867 from the U. S. Public Health Service.

\section{REFERENCES}

1. Mackenzie, I. L., R. M. Donaldson, Jr., and R. F. Schilling. 1967. Iodination of human intrinsic factor. J. Clin. Invest. 46: 1089. (Abstr.)

2. Mackenzie, I. L., R. M. Donaldson, Jr., and R. F Schilling. 1968. Reactions of binding and blocking antibodies with ${ }^{125} \mathrm{I}$-labeled human intrinsic factor. Clin. Res. 16: 287. (Abstr.)

3. Chosy, J. J., and R. F. Schilling. 1963. Intrinsic factor studies. VII. The use of ion-exchange chromatography, gel filtration and ultrafiltration to purify the intrinsic factor of human gastric juice. J. Lab. Clin. Med. 61: 907.

4. Greenwood, F. C., W. M. Hunter, and J. S. Glover. 1963. The preparation of $\mathrm{I}^{131}$ labelled human growth hormone of high specific activity. Biochem. J. 89: 114.
5. Hirs, C. H. W., S. Moore, and W. H. Stein. 1953. A chromatographic investigation of pancreatic ribonucleuse. J. Biol. Chem. 200: 493.

6. Johnson, M. J. 1941. Isolation and properties of a pure yeast polypeptidase. J. Biol. Chem. 137: 575.

7. Gottlieb, C., K-S Lau, L. R. Wasserman, and V. Herbert. 1965. Rapid charcoal assay for intrinsic factor (IF), gastric juice unsaturated $\mathrm{B}_{12}$ binding capacity, antibody to IF, and serum unsaturated $\mathrm{B}_{12}$ binding capacity. Blood. 25: 875 .

8. Smithies, O. 1955. Zone electrophoresis in starch gels: group variations in the serum proteins of normal human adults. Biochem. J. 61: 629 .

9. Schilling, R. F. 1953. Intrinsic factor studies. II. The effect of gastric juice on the urinary excretion of radioactivity after the oral administration of radio-active vitamin B $\mathrm{B}_{12}$. J. Lab. Clin. Med. 42: 860.

10. Taylor, K., I. Roitt, M. Doniach, K. Couchman, and C. Shapland. 1962. Autoimmune phenomena in pernicious anemia: gastric antibodies. Brit. Med. J. 2: 1347.

11. Jeffries, G. M., D. Hoskins, and M. Sleisenger. 1962. Antibody to intrinsic factor in serum from patients with pernicious anemia. J. Clin. Invest. 41: 1106.

12. Schade, S. G., J. Abels, and R. F. Schilling. 1967. Studies on antibody to intrinsic factor. J. Clin. Invest. 46: 615 .

13. Imrie, M., and R. F. Schilling. 1965. Studies of antibodies to intrinsic factor. J. Lab. Clin. Med. 66: 880. (Abstr.)

14. Schade, S. G., P. L. Feick, M. M. Imrie, and R. F. Schilling. 1967. In vitro studies on antibodies to intrinsic factor. Clin. Exp. Immunol. 2: 399.

15. Simons, K. 1964. Vitamin $B_{12}$ binders in human body fluids and blood cells. Soc. Sci. Fenn. Commentat. Biol. 27: 5 .

16. McGuigan, J. E. 1967. Measurement of the affinity of human gastric intrinsic factor for cyanocobalamin. $J$. Lab. Clin. Med. 70: 666.

17. Cooper, B. A. 1964. The uptake of ${ }^{57} \mathrm{Co}$-labelled vitamin $\mathrm{B}_{12}$ by everted sacs of intestine in vitro. Medicine. 43: 639.

18. Grasbeck, R., K. Simons, and I. Sinkkowen. 1966. Isolation of intrinsic factor and its probable degradation product, as their vitamin $\mathrm{B}_{12}$ complexes, from human gastric juice. Biochim. Biophys. Acta. 127: 47. 